\title{
Logistic Cost Analysis of Rice Straw to Optimize Power Plant in Malaysia
}

\author{
S.M. Shafie ${ }^{a,{ }^{*}}$, T.M.I. Mahlia ${ }^{\text {b,c }}$, H.H. Masjuki ${ }^{a}$ and W.T. Chong ${ }^{a}$ \\ ${ }^{a}$ Department of Mechanical Engineering, University of Malaya, 50603 Kuala Lumpur, Malaysia \\ ${ }^{b}$ Department of Mechanical Engineering, Universiti Tenaga Nasional, 43009 Kajang, Selangor, Malaysia \\ ${ }^{c}$ Department of Mechanical Engineering, Syiah Kuala University, Banda Aceh 23111, Indonesia
}

\begin{abstract}
This paper presents a logistic cost analysis of rice-straw based power generation. Mathematical logistic models were developed to determine collection, storage and transportation costs of rice-straw based power generation. The optimization technique was used to identify the location of power plant and optimum number of storage facilities. The results indicated that transportation costs were the highest of the logistic costs, contributing $54 \%$ to $63 \%$ of the total logistic costs and that transportation of rice straw to collection centres contributed $89.9 \%$ of the total transportation costs due to effect of truck capacity. Reduction in the number of storage facilities would improve transportation cost.
\end{abstract}

Keywords: Rice straw, Cost analysis, Logistic operations, Power plants, Malaysia.

\section{INTRODUCTION}

Currently, Malaysia electricity generation depends heavily on fossil fuel resources [1]. In 2011, 94\% of the total generation mix in Peninsular Malaysia was from fossil resources. However, Malaysia is an agriculture country with tropical weather and has an abundance of oil palm waste, wood waste, and agriculture residue that, if utilized property, could contribute significantly to biomass energy [2, 3]. Biomass fuel contributes $16 \%$ to the energy consumption in the country, to which $51 \%$ comes from palm oil waste, $27 \%$ from wood waste and $2 \%$ from paddy residues [4]. About $2.39 \mathrm{M}$ tonnes of paddy residue were created in $2010 ; 77.3 \%$ of them were rice straw. Although rice straw provides great potential for energy production, its consumption remains less compared to that of rice husks [5].

Open burning is the current usage pattern of rice straw in Malaysia; the same is true in Thailand with $48 \%$ and in Philippines (95\%) open burning activities involved [6]. Many countries have started exploring the potential use of rice straw in different applications [710]. The potential benefits of rice straw use include improving air quality, solving the disposal problem and reducing dependency on fossil fuel for energy generation.

The low energy density of rice straw fuels compared to that of fossil fuel makes transportation an issue and a relevant cost factor in power generation system [11]. The logistic cost of biomass is a key component of the

*Address correspondence to this author at the Department of Mechanical Engineering, University of Malaya, 50603 Kuala Lumpur, Malaysia; Tel: +60-17-499-4562; Fax: +60-4-919-0015; E-mail: shafini@uum.edu.my overall cost to recover fuels, contributing $35-50 \%$ of the total production cost [12]. The authors realized the importance of cost analysis for developing biomass energy [13-16]. Hence, it is vital to consider logistic factors to assess the economics of using rice straw as a source of energy [17].

In this study, we discuss the logistic aspect of ricestraw based power generation. The aims of this paper are to (1) determine the logistic cost of using rice straw in a power plant and (2) identify the optimum of operated power plant. We focus on understanding the cost relationships between rice straw collection, transportation of rice straw to collection centres (storage), storage, and transportation to power plants.

\section{PREVIOUS LITERATURE ON LOGISTIC ISSUE OF BIOMASS}

Much previous research has stated that the highest cost of biomass-based power generation is contributed by logistic cost [11, 12, 18-20]. In general, the cost of transporting biomass is more than the cost of transporting its energy products [21]. Different types of biomass resources have different impacts upon the logistic cost. Table 1 summarizes the main parameter impacts to logistic cost from previous literature.

\section{COLLECTED DATA AND METHODOLOGY}

Costs are based on Ringgit Malaysia (1RM $=\$ 0.31)$. The model includes all physical components such as machinery for rice straw collection, transportation type, fuel and labour, which affect the logistic cost of rice straw. The overall processes from the collection of rice straw at the paddy field to the transportation of the 
Table 1: Main Parameter Impact to Logistic Cost

\begin{tabular}{|c|c|c|c|c|}
\hline Parameter & Impact to logistic cost & Biomass type & Country & Author \\
\hline $\begin{array}{c}\text { Distribution of efficient biomass } \\
\text { management }\end{array}$ & Minimising the transportation cost & Any type & Spain & [22] \\
\hline $\begin{array}{l}\text { Effective and efficient planning of } \\
\text { logistic operation }\end{array}$ & Minimising the transportation cost & Agriculture crop & Canada & [23] \\
\hline $\begin{array}{l}\text { Rising the transport-vehicle } \\
\text { capacities }\end{array}$ & Minimum cost of transportation & Cotton plant stalks & $\begin{array}{l}\text { Greece and } \\
\text { Europe }\end{array}$ & [24] \\
\hline $\begin{array}{l}\text { Maximized the truck utilization } \\
\text { factor(loads hauled per day) }\end{array}$ & Minimized the transportation cost & Herbaceous biomass & United State & [25] \\
\hline Increased size of power plants & $\begin{array}{l}\text { Logistic constraints on economic } \\
\text { performances become less restrictive }\end{array}$ & $\begin{array}{l}\text { Agriculture crops, agro- } \\
\text { industrial and wood waste }\end{array}$ & Italy & {$[20]$} \\
\hline Biomass storage & $\begin{array}{l}\text { Leads a significant role to the biomass } \\
\text { logistics }\end{array}$ & $\begin{array}{l}\text { Cotton stalk and almond tree } \\
\text { pruning }\end{array}$ & Greece & [18] \\
\hline Site productivity & $\begin{array}{l}\text { A high productivity plantation would } \\
\text { reduce the transportation cost }\end{array}$ & Eucalyptus & United State & [15] \\
\hline Increased the bulk density & Reduce transportation cost & $\begin{array}{l}\text { Agricultural and woody } \\
\text { biomass }\end{array}$ & Canada & [12] \\
\hline $\begin{array}{l}\text { More efficient collection and } \\
\text { transport system developed }\end{array}$ & Reduce transportation cost & Corn Stover & United State & [26] \\
\hline
\end{tabular}

baled to the power plant are covered in this paper. An overview of developed logistic model is shown in Figure 1. Two interview sessions were carried to obtain data for the each zone that had implemented rice straw collection as its mini project.

The baseline model is developed for nominal 10MW. An annual demand was calculated using Eq. (1) [27]. Table 2 listed the assumption made for this analysis.

$R S_{A D}=\left(P_{O} \times h_{P O}\right) /\left(\eta \times L H V_{R S}\right)$

\subsection{Estimated Rice Straw Availability and Area}

The rice straw availability is estimated using SGR (Straw to grain ratio). In this study Eq. (2) using a 0.75 ratio estimated the availability of rice straw [32]. Table 3 indicated the paddy production for each zone in the study area.

$Q_{R S}=P_{R R} \times S G R$

Logistic cost is related to spatial distribution of rice straw. For this study, the assumption was made that the collection centre and power plant locations were at centre of a circular catchment area. The distance of collection centre $\left(d_{\mathrm{a}, \mathrm{T} 1}\right)$ and power plant $\left(d_{\mathrm{a}, \mathrm{T} 2}\right)$ was calculated using Eq. (3). For each component, this number was divided into subcomponents based on real allocations of Muda Agricultural Development Authority (MADA) management. Three project managers of rice straw management in MADA areas were interviewed to

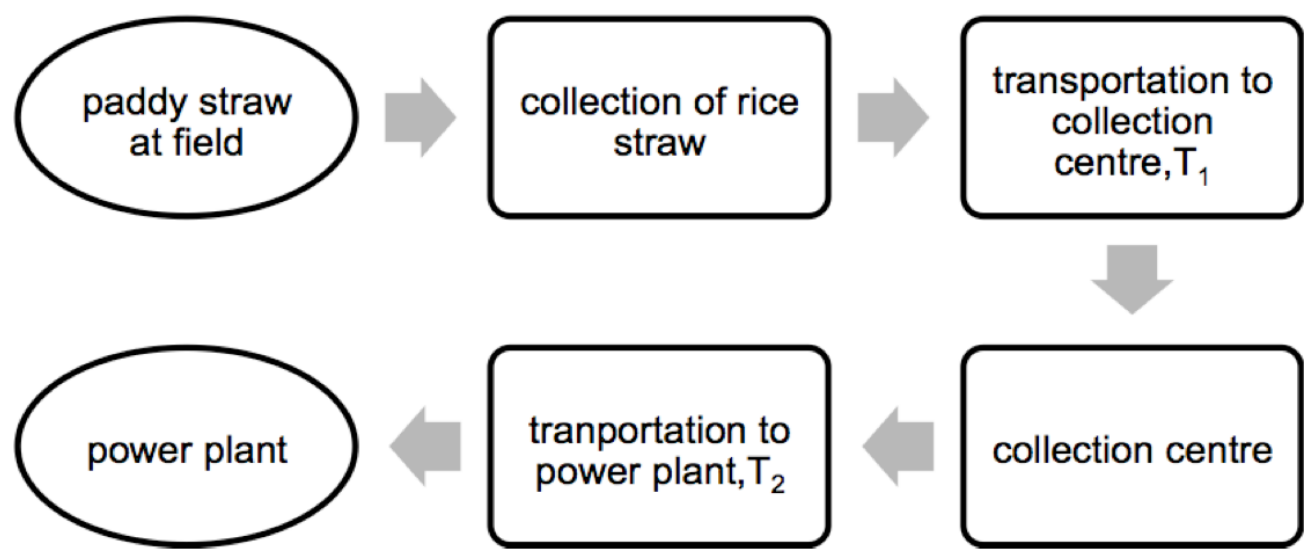

Figure 1: An overview of logistic model. 
Table 2: Assumed Parameter for Estimating the Rice Straw Demanding

\begin{tabular}{|c|c|}
\hline \multicolumn{2}{|c|}{ Assumption } \\
\hline \hline \multicolumn{2}{|c|}{ Rice straw demanding } \\
\hline Power capacity & $10 \mathrm{MW}$ \\
\hline Annual operating hour & $8472 \mathrm{~h}$ \\
\hline Overall efficiency of power plant & $23 \%$ \\
\hline LHV of rice straw & $13.55 \mathrm{MJ} / \mathrm{kg}$ \\
\hline Moisture content & $11 \%$ \\
\hline Annual rice straw demand(db) & 97863.63 tonne/year \\
\hline Actual annual rice straw demand & 108628.6 tonne/year \\
\hline Cost of Collection Centre (storage) \\
\hline \multicolumn{2}{|c|}{ Interest rate } \\
\hline DML for open side structure & $3 \%[28]$ \\
\hline Investment year & $3-10 \%[29]$ \\
\hline Capital Cost & 20 years [30] \\
\hline
\end{tabular}

examine their current management process for rice straw. Only two of the units managed their own rice straw; these were B-II and F-IV. The others used a subcontractor to manage the process. For this study, each unit was assumed to have a collection centre, and the optimal power plant location was assumed to be in the centre of each zone.

$$
\begin{aligned}
& d_{a, T 1}=\sqrt{\left(\left(R S_{A D} / R S_{Y, s b c o m p A}\right) / \pi\right)} \\
& d_{a, T 2}=\sqrt{\left(\left(R S_{A D} / R S_{Y, c o m p 1}\right) / \pi\right)}
\end{aligned}
$$

\subsubsection{Collection of Rice Straw}

Total annual machinery costs were the summation of fixed cost and operating cost. Fixed cost included depreciation, interest and insurance [33]. The depreciation cost was calculated through Eq. (5) [27, 33].

$$
C_{D E P}=\left(C_{N E W}-C_{N E W} \times(R F V / 100)\right) / L T
$$

\begin{tabular}{|c|c|c|c|c|}
\hline Zone & Unit & Area $\left(\mathrm{km}^{2}\right)$ & Paddy production (ton) & Rice straw availability (ton) \\
\hline \multirow[t]{6}{*}{1} & & 186.76 & $219,835.20$ & $164,876.40$ \\
\hline & A & 38.47 & & \\
\hline & $\mathrm{B}$ & 34.96 & & \\
\hline & $\mathrm{C}$ & 16.89 & & \\
\hline & $\mathrm{D}$ & 39.72 & & \\
\hline & $\mathrm{E}$ & 56.72 & & \\
\hline \multirow[t]{10}{*}{ II } & & 316.16 & $377,052.42$ & $282,789.32$ \\
\hline & A & 28.66 & & \\
\hline & $\mathrm{B}$ & 37.79 & & \\
\hline & $\mathrm{C}$ & 38.55 & & \\
\hline & $\mathrm{D}$ & 40.21 & & \\
\hline & $E$ & 38.78 & & \\
\hline & $\mathrm{F}$ & 35.23 & & \\
\hline & $\mathrm{G}$ & 29.40 & & \\
\hline & $\mathrm{H}$ & 26.47 & & \\
\hline & 1 & 41.07 & & \\
\hline \multirow[t]{7}{*}{ III } & & 213.76 & $238,406.53$ & $178,804.89$ \\
\hline & A & 43.56 & & \\
\hline & $\mathrm{B}$ & 32.97 & & \\
\hline & $\mathrm{C}$ & 36.15 & & \\
\hline & $\mathrm{D}$ & 44.28 & & \\
\hline & $\mathrm{E}$ & 31.48 & & \\
\hline & $\mathrm{F}$ & 25.32 & & \\
\hline \multirow[t]{8}{*}{ IV } & & 248.90 & $313,688.67$ & $235,266.50$ \\
\hline & A & 34.32 & & \\
\hline & $\mathrm{B}$ & 23.39 & & \\
\hline & $\mathrm{C}$ & 37.02 & & \\
\hline & $\mathrm{D}$ & 37.59 & & \\
\hline & $E$ & 44.93 & & \\
\hline & $\mathrm{F}$ & 35.97 & & \\
\hline & $G$ & 35.68 & & \\
\hline
\end{tabular}

Table 3: Paddy Production in 2010 
Table 4: Major Parameter for the Machinery [33]

\begin{tabular}{|c|c|c|c|c|}
\hline \multirow{2}{*}{ Machinery } & \multirow{2}{*}{ Estimated life (h)-years } & \multirow{2}{*}{ RFV } & \multicolumn{2}{|c|}{ Repair Factor } \\
\cline { 3 - 5 } & & & RF1 & 2.0 \\
\hline \hline Tractor & $(3750)-15$ & 27.08 & 0.07 & 1.0 \\
\hline Round Baler & $(3750)-15$ & 23.00 & 0.43 & 2 \\
\hline
\end{tabular}

Operating cost included the annual repair and maintenance of machinery was used Eq. (6) and Eq. (7) $[27,33,34]$. The parameters used for determining the operating cost are listed in Table 4.

$C_{R M}=C_{N E W} \cdot\left(A R M_{C} / L T\right)$

$A R M_{C}=(R F 1) \cdot(h / 1000)^{R F 2}$

Average consumption of diesel is given by Eq. (8) [33]

$C_{F}=0.73 \cdot 0.06 \cdot P T O \cdot P_{F} \cdot h$

Table 5 shows the machinery operating cost for B-II area and was based on interview session with the project manager of B-II area [35].

\subsubsection{Transportation of Baled Rice Straw to Collection Centre $\left(T_{1}\right)$}

The transportation cost from the paddy field to the collection centre is given by Eq. (9). These costs were related to transportation distance, lorry capacity and personnel cost for driver [19, 36]. For the purposes of this study, the following assumptions were made: that a 1-tonne lorry was used for transportation to the collection centre, diesel was consumed at 0.105 litre $/ \mathrm{km}$, and 2 bales of rice straw would be loaded per lorry, with $450 \mathrm{~kg}$ per bale.

$C_{T 1}=\left(\left(0.105 \cdot F \cdot d_{a, T 1}\right)+\left(S C T P \cdot d_{a, T 1}\right)\right) / T_{C 1}$

\subsubsection{Collection Centre}

The purpose of a collection centre is to maintain the number of rice straw bales at the desired level. Some studies have located the collection centre on site [34, 36], while several authors have considered a collection site that was equidistant between the field and power plant [12, 24, 27, 37, 38]. For this study, it was assumed that a collection centre was at current location of rice straw collection under MADA management. The centre of unit was assumed to be the location of collection centre (storage). Currently available collection centres were at B-II and F-IV. Collection of rice straw in this area was for small quantities used for feeding animals. The cost of collection centre (storage) was the sum of storage site and considered the cost of dry matter lost during storage [30]. The type of storage facilities affected the storage cost. Bales were in open storage because a round bale can tolerate exposure to rain and weather conditions [11].

$C_{A, C C}=P P \cdot\left(i / 1-(1+i)^{-n}\right)$

Where $C_{A, C C}$ annual capital cost (RM), PP is purchase price $(\mathrm{RM}), i$ is interest rate and $n$ life of investment year.

$C_{C C}=\left(C_{A, C C} / W_{C C}\right) \cdot(1 / 1-D M L)$

DML is dry matter loss in the collection centre in tonne.

\subsubsection{Collection Centre to Power Plants Transportation $\left(T_{2}\right)$}

Transportation costs of moving rice straw to the power plant are derived from Eq.12. A truck weighing 3.5 tonnes with a 40 -foot length is used to transport the bales $[35,39]$. The average fuel consumption is 0.27

Table 5: Machinery Operating Cost

\begin{tabular}{|c|c|c|c|c|c|c|}
\hline Machine & Cost & Depreciation & Repair Cost & PTO & Fuel Cost & Total \\
\hline \hline Tractor & \multicolumn{7}{|l|}{} \\
\hline New Holland & 75000 & 3646 & 49218.8 & 96.3 & 1898.5 & 59814.7 \\
\hline Fiat & 60000 & 2916.8 & 39375 & 80 & 1576.8 & 47909.7 \\
\hline Farm track & 50000 & 2430.7 & 32812.5 & 67.1 & 1323.1 & 39933.9 \\
\hline Dongfeng & 65000 & 3159.9 & 42656.2 & 80 & 1576.8 & 51770.8 \\
\hline Baler & 100000 & 5133.3 & 107500.0 & & & \\
\hline
\end{tabular}


Table 6: Estimated the Rice Straw Collection Cost at Field

\begin{tabular}{|c|c|c|c|c|c|}
\hline \multirow{2}{*}{ Zone } & \multicolumn{5}{|c|}{ Cost (RM/bale) } \\
\cline { 2 - 6 } & Fuel & Labour & Twine & Machinery & Total \\
\hline \hline II & 1.79 & 15 & 1.64 & 4.01 & 22.43 \\
\hline IV & 1.52 & 26 & & 4.81 & 32.33 \\
\hline
\end{tabular}

litres per $\mathrm{km}$ [19]. The bale capacity per truck is 36 bales.

$$
C_{T 2}=\left(\left(0.27 \cdot F \cdot d_{a, T 2}+\left(S C T P \cdot d_{a T 2}\right) / T_{C 2}\right.\right.
$$

\subsection{OPTIMUM SUPPLY OF POWER GENERATION}

The Logistic Model adapted from Simple Plant Location Problem (SPL) was applied in order to obtain the optimum location of power plant. The following equation is derived to minimize the cost for logistic analysis of rice straw to the power plant.

\section{Minimize}

$\sum_{i=1}^{n} f_{i} y_{i}+\sum_{i=1}^{n} \sum_{j=1}^{m} c_{i j} x_{i j}$

It is specified as follows:

$n=$ number of zone which a plant may be located (4 zone)

$m=$ number of collection centre (storage) available

$f_{i}=$ summation of collection cost and collection centre cost(storage cost) of having a plant site $i$, for $i=1.2 . . n$.

$c_{i j}=$ average summation transportation cost $\left(\mathrm{T}_{1}\right.$ and $\mathrm{T}_{2}$ ) of assigning from collection centre $j$ to a plant site $i$, for $1=1,2, . . n$ and $j=1,2, . . m$.

Within the approach The parameter of LHV [40] and derived equation from [6] was used to measure the optimum power generation.

\section{RESULTS AND DISCUSSION}

\subsection{Case Study Description}

A model of a rice straw power plant has been developed for an exemplary study in Malaysia. This case examines a paddy plantation under the Muda Agricultural Development Authority (MADA), in Kedah, which is the main area for paddy plantations in Malaysia. Figure 1 shows an overview of the logistic model. For the convenience of MADA management, the area is divided into 4 zones; I, II, III and IV. Each zone is broken down into several units (Refer Table $\mathbf{3}$ ). Currently, there are four pilot projects for rice straw collection under MADA management with overall production of 2880 tonnes in 2010 , which utilized only $0.33 \%$ of total available of rice straw in the MADA area. Unfortunately, zone 1 is not included in the rice straw projects.

\subsection{Cost of Logistic Operations}

The analysis of cost of logistic is based on a baseline project that generated $10 \mathrm{MW}$ electricity with rice straw consumption of 108,629 tonnes per year according to the assumption made in Table 2. These calculations are based on 0.75 rice straw availability in the field. Table 6 lists the total collection cost of rice straw in the fields (only harvesting process). These include the machinery cost, fuel cost, labour cost and twine cost. Total rice straw collection in Malaysia is lower than rice straw collection in Thailand [27]. The mass of a standard bale size is set at $450 \mathrm{~kg}$ and that of a big bale size at $600 \mathrm{~kg}$. Increasing the straw yield would reduce the cost of rice straw collection at field by about $50 \%$. These sensitivity of rice straw collection costs as those costs vary with straw yield is shown in Figure 2. The simulation predicts that the standard bale size decreased by $73.1 \%$ when yield is increased by $100 \%$. While the big bale size decreased by $75 \%$ when yield is increased by $100 \%$. This results show similar patterns with [15], in that a high productivity of yield

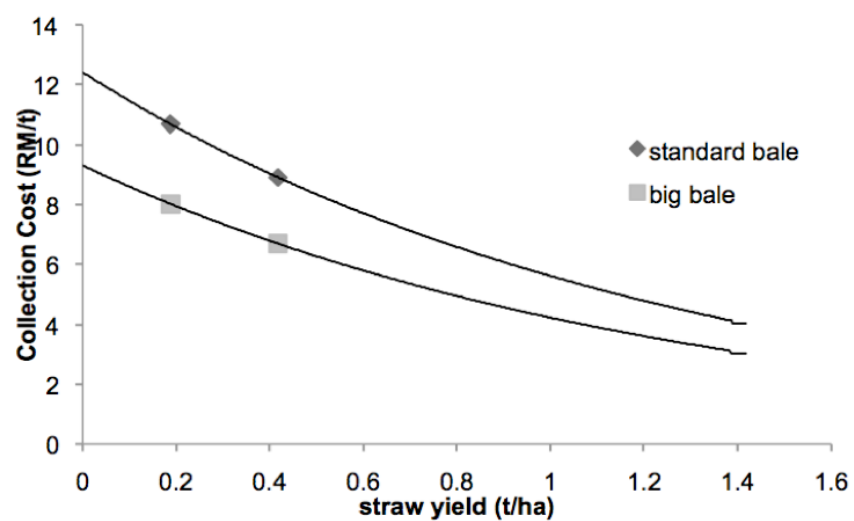

Figure 2: Cost for field collection of rice straw in the function of straw yield. 
Table 7: Total Collection Centre Cost

\begin{tabular}{|c|c|c|c|c|}
\hline Zone & Cost Building & $\mathbf{C}_{\mathrm{A}, \mathrm{cc}}$ & $\mathbf{C}_{\mathrm{cc}}($ RM/Dry Tonne) & $\mathbf{C}_{\mathrm{cc}}$ (RM/Bale) \\
\hline \hline $\mathrm{II}$ & 254459.79 & 17103.69 & 13.18 & 8.48 \\
\hline $\mathrm{IV}$ & 109049.30 & 7329.83 & 14.99 & 9.65 \\
\hline
\end{tabular}

would reduce cost. Even though big bale size reduces collection cost, the bale creates a transportation problem due to larger size.

Table 7 indicates the total collection centre (storage cost) cost. This cost depends upon building cost. The optimum collection cost is obtained by fully maximizing building capacity. Figure $\mathbf{3}$ showing the relationship between collection centre costs versus moisture and building cost. Zone II rice straw capacity output was 3600 bales while Zone IV was 1500 bales. Total collection centre costs contribute $11 \%$ to the overall logistic cost. Increase of moisture loss also increases collection centre costs. It was similar with building cost. But building cost is most affected by the changing collection centre costs.

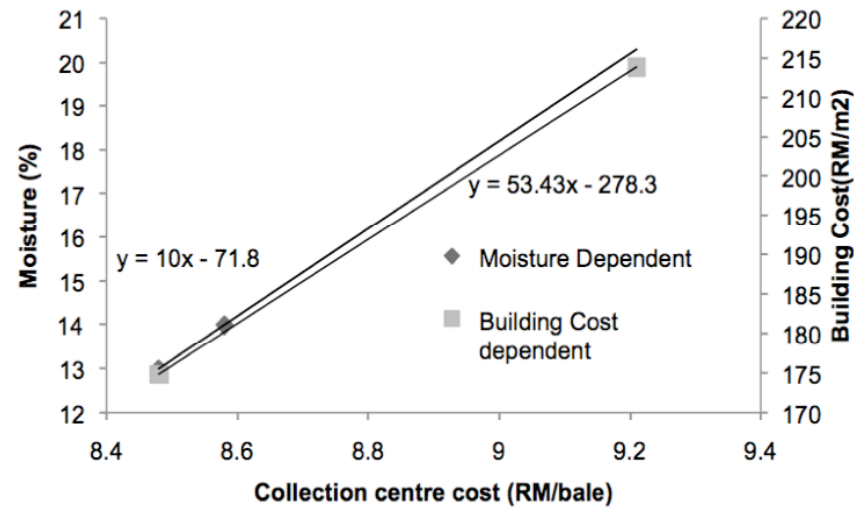

Figure 3: Collection centre cost versus moisture (\%) and building cost $\left(\mathrm{RM} / \mathrm{m}^{2}\right)$.

Transportation of rice straw considers transportation to collection centre (storage) and to power plant. The most significant affect to transportation cost is from the distance variable. Transportation of rice straw to collection centre, $\mathrm{T}_{1}$ contributes $89.9 \%$ the total cost (Figure 4). This is due to the small capacity of a 1tonne lorry. This means that truck capacity has an impact upon the transportation cost. A large size truck can reduce the vehicle kilometres and increase the fuel consumption per trip hence reducing transportation cost [12]. Figure 4 show transportation cost associated with various travel distances.

By looking the various activities, the cost that contributes the most to the logistic costs is transportation. Transportation accounts for $54-64 \%$ of total logistic cost. Collection and collection centre costs have limited effects on the logistic cost. The outcome is similar to that of solid biomass transport in Western European plantations [41]. For this reason, it was important to identify the optimum location of power plant that could minimize the logistic cost. Figure 5 indicates the graph for breakdown logistic costs for Zone I and Zone IV.

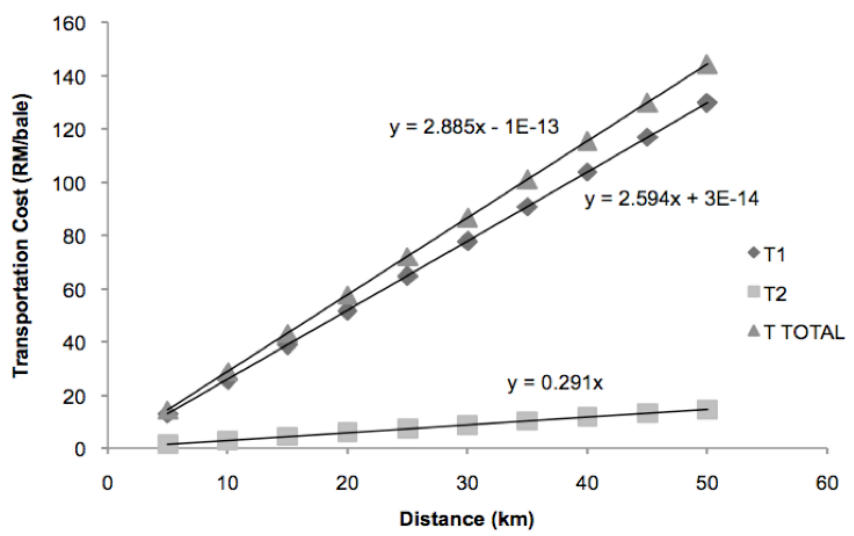

Figure 4: Trend of transportation cost of various traveldistances.

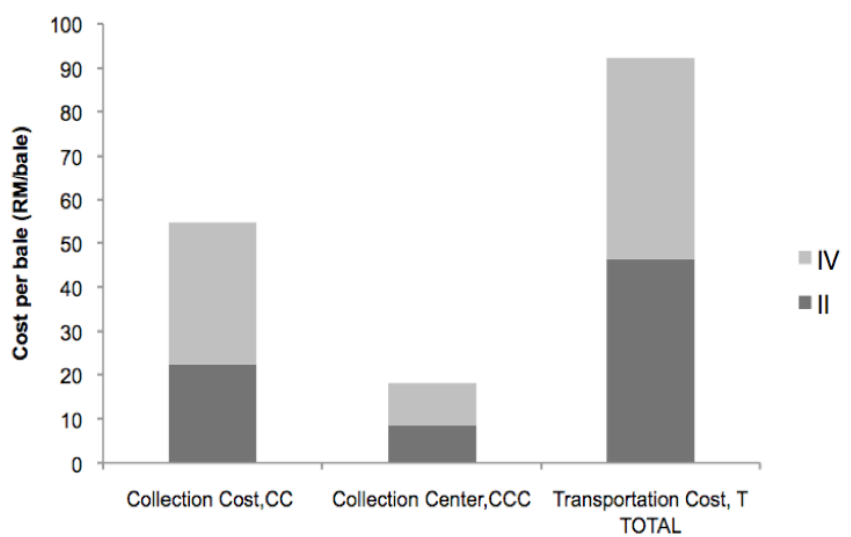

Figure 5: Breakdown logistic cost for Zone 1 and Zone IV.

\subsection{Optimum Analysis}

The analysis of optimum rice-straw based power generation with minimum costs has been done is Zone II and Zone IV. It observed that Zone II power optimum is $8 \mathrm{MW}$ and Zone IV is $12.22 \mathrm{MW}$. Total logistic cost for Zone II rice straw power is RM 74.07 per bale which is $11.07 \%$ less than Zone IV. The limitation factors of 
Table 8: Analysis of Optimum Power Plant

\begin{tabular}{|c|c|c|}
\hline Area & Zone II & Zone IV \\
\hline \hline Optimum Power (MW) & 8 & 12.22 \\
\hline Collection Centre & Unit H- Kepala Batas & $\begin{array}{c}\text { Unit A4-Seri Pantai } \\
\text { Unit B4-Tun Adam Malik }\end{array}$ \\
\hline Cost(RM/bale) & 74.07 & 83.9 \\
\hline Number of bale required & 48607 & 73810 \\
\hline
\end{tabular}

collecting and transporting made the rice straw power generating facilities tend to be small; most of the biomass projects are relatively small, $61 \%$ are less than $10 \mathrm{MW}$ in Southeast Asia [42]. Table 8 shows the detailed results from the analysis of optimum power plant.

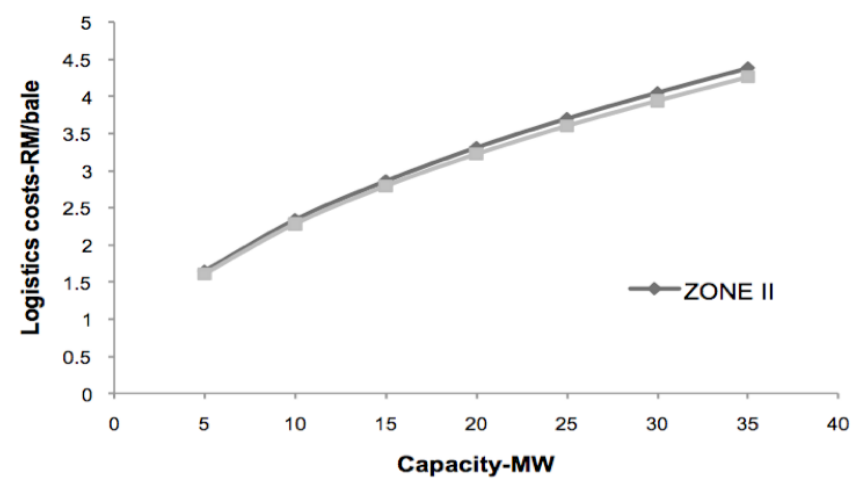

Figure 6: Rice straw logistics costs scaling.

Figure 6 shows logistic cost for different capacity output. The logistic cost increases with the increased size of plant capacity. The reason for the cost variation for two zones is related to their straw yields productivity which, in general the catchment area for zone II is $316.16 \mathrm{~km}^{2}$ while for zone IV is $248.90 \mathrm{~km}^{2}$. For small capacity below $15 \mathrm{MW}$, the logistic costs for both zones appear similar and recognize distinguishing after $20 \mathrm{MW}$

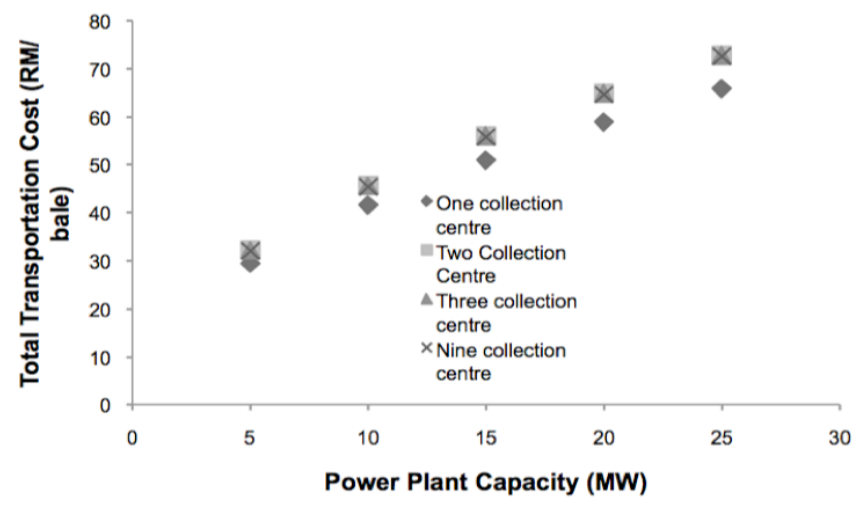

Figure 7: Total transportation cost for different number of collection centre.
Figure 7 shows the total transportation cost for different numbers of collection centre. Increasing the number of collection centres will increase the transportation cost. With respect to small power plant capacity of less than $10 \mathrm{MW}$, the number of collection centres is not significant with repect to total transportation cost. Minimising the number of collection centres can minimize the transportation cost when the capacities of power plant increase.

\section{CONCLUSION}

A cost analyses shows that there is an option to supply rice straw to a projected power plant in the Northern region of Malaysia due to high availability of rice straw. Logistics chains from the start include: rice straw collection, collection centre (storage) and transportation. A through cost analysis indicated that transportation costs are the highest logistic costs contributing from $54 \%$ to $63 \%$ from total of logistic cost. Transportation of rice straw to collection centre, $\mathrm{T}_{1}$ contributes $89.9 \%$ to the total cost. Truck capacity has a significant impact upon the transportation cost. Total collection centre costs contribute $11 \%$ to the overall logistic cost and increasing the straw yield could reduce costs of rice straw collection at field about $50 \%$.

In the future, Malaysia can potentially generate power on a small scale (less than 12MW) with rice straw-based power plants. Minimising the number of collection centre (storage) is one solution to lower transportation costs with higher power plant capacity applications. The logistic cost analysis study in this research could help to optimize the supply chain and evaluate the economic profitability of biomass resources.

\section{ACKNOWLEDGEMENTS}

The authors would like to acknowledge the Ministry of Higher Education of Malaysia and The University of Malaya, Kuala Lumpur, Malaysia for financial support under UM.C/HIR/MOHE/ENG/15 (D000006-16001). 
And I would like to thank Dr. Timothy Walters for his helping for proofreading of this paper.

\section{NOMENCLATURE}

$$
\begin{aligned}
& A R M_{C}=\text { Accumulated repair and maintenance } \\
& \text { coefficient } \\
& C_{C C}=\text { Annual cost of storage rice straw }(\mathrm{RM}) \\
& C_{D E P}=\text { Depreciation Cost (RM) } \\
& C_{F} \quad=\quad \text { Fuel Cost }(\mathrm{RM}) \\
& C_{N E W}=\text { New Cost (RM) } \\
& C_{R M}=\text { Repair and Maintenance Cost (RM) } \\
& C_{T 1}=\text { Transportation cost of baler from paddy } \\
& \text { field to collection centre (RM) } \\
& C_{T 2}=\text { Transportation cost of baler from collection } \\
& \text { centre to power plants (RM) } \\
& d_{a, T 1}=\text { Average distance from paddy field to } \\
& \text { collection centre }(\mathrm{km}) \\
& d_{a, 72}=\text { Average distance from collection centre to } \\
& \text { power plant }(\mathrm{km}) \\
& \mathrm{DML}=\text { Dry matter loss }(\%) \\
& h=\text { Use hour of machine annually (h) } \\
& h_{P O}=\text { Plant operating hour }(\mathrm{h}) \\
& L H V_{R S}=\text { Rice straw low heating value }(\mathrm{MJ} / \mathrm{kg}) \\
& L T \quad=\quad \text { Life time (year) } \\
& \eta \quad=\text { Efficiency } \\
& \text { PTO = Power takes off } \\
& P_{F} \quad=\text { Fuel price }(\mathrm{RM} / \text { Litre }) \\
& P_{O} \quad=\text { Electrical output }(\mathrm{MW}) \\
& P_{R R} \quad=\text { Rough rice production (tonne) } \\
& Q_{R S}=\text { Quantity of rice straw (tonne) } \\
& R F 1=\text { Repair and maintenance factor } \\
& \text { RF2 = Repair and maintenance factor } \\
& \text { RFV = Remaining Farm Value }
\end{aligned}
$$

\author{
$R S_{A D}=$ Annual demand of rice straw (tonne/year) \\ SGR = Straw grain ratio \\ $W_{C c}=$ Mass of rice straw in collection centre \\ (tonne)
}

\section{REFERENCES}

[1] Shafie SM, et al. Current energy usage and sustainable energy in Malaysia: A review. Renewable Sustainable Energy Rev 2011; 15(9): 4370-77. http://dx.doi.org/10.1016/j.rser.2011.07.113

[2] Mekhilef S, et al. Biomass energy in Malaysia: Current state and prospects. Renewable Sustainable Energy Rev 2011; 15: 3360-70.

http://dx.doi.org/10.1016/j.rser.2011.04.016

[3] Ong HC, Mahlia TMI, Masjuki HH. A review on energy scenario and sustainable energy in Malaysia. Renewable Sustainable Energy Rev 2011; 15: 639-47. http://dx.doi.org/10.1016/j.rser.2010.09.043

[4] Ali R, Daut I, Taib S. A review on existing and future energy sources for electrical power generation in Malaysia Renewable Sustainable Energy Rev 2012; 16(6): 4047-55. http://dx.doi.org/10.1016/j.rser.2012.03.003

[5] Binod $P$, et al. Bioethanol production from rice straw: An overview. Bioresource Technol 2010; 101(13): 4764-74. http://dx.doi.org/10.1016/j.biortech.2009.10.079

[6] Gadde B, Menke C, Wassmann R. Rice straw as a renewable energy source in India, Thailand and Philippines: Overall potential and limitations for energy contribution and greenhouse gas mitigation. Biomass Bioenergy 2009; 33: 1532-1546.

http://dx.doi.org/10.1016/j.biombioe.2009.07.018

[7] Matsumura Y, Minowa T, Yamamoto H. Amount, availability and potential use of rice straw(agricultural residue) biomass as energy resource in Japan. Biomass Bioenergy 2005; 29: 347-54. http://dx.doi.org/10.1016/j.biombioe.2004.06.015

[8] Diep NQ, et al. Estimation of the potential of rice straw for ethanol production and the optimum facility size for different regions in Vietnam. Appl Energy 2012; 93: 205-11. http://dx.doi.org/10.1016/j.apenergy.2011.12.074

[9] Hiloidhari $M$, Baruah DC. Rice straw residue biomass potential for decentralized electricity generation: A based study in Lakhimpur district of Assam, India. Energy Sustainable Dev 2011; 15: 214-22. http://dx.doi.org/10.1016/i.esd.2011.05.004

[10] Suramaythangkor T, Gheewala SH. Potential alternatives of heat and power technology application using rice straw in Thailand. Appl Energy 2010; 87: 128-33. http://dx.doi.org/10.1016/j.apenergy.2009.06.018

[11] Gold S, Seuring S. Supply chain and logistics issues of bioenergy production. J Cleaner Prod 2011; 19: 32-42. http://dx.doi.org/10.1016/i.jclepro.2010.08.009

[12] Sultana A, Kumar A. Optimal configuration and combnation of multiple lignocellulosic biomass feedstocks delivery to a bioenergy. Bioresource Technol 2011; 102(21): 9947-56. http://dx.doi.org/10.1016/j.biortech.2011.07.119

[13] Rogers JG, Brammer JG. Analysis of transport costs for energy crops for use in biomass pyrolysis plant networks. Biomass Bioenergy 2009; 33: 1367-75.

http://dx.doi.org/10.1016/j.biombioe.2009.05.018

[14] Kamimura K, Kuboyama H, Yamamato K. Wood biomass supply costs and potential for biomass energy plants in Japan. Biomass Bioenergy 2012; 36: 107-15. http://dx.doi.org/10.1016/j.biombioe.2011.10.020 
[15] Gonzalez R, et al. Exploring the potential of Eucalyptus for energy production in the Southern United States:Financial analysis of delivered biomass. Part 1. Biomass Bioenergy 2011; 35: 755-66.

http://dx.doi.org/10.1016/j.biombioe.2010.10.011

[16] Yagi K, Nakata T. Economic analysis on small scale forest gasification considering geographical resources distribution and technical characteristics. Biomass Bioenergy 2011; 35: 2883-92.

http://dx.doi.org/10.1016/j.biombioe.2011.03.032

[17] Lim JS, et al. A review on utilisation of biomass from rice industry as a source of renewable energy. Renewable Sustainable Energy Rev 2012; 16(5): 3084-94. http://dx.doi.org/10.1016/j.rser.2012.02.051

[18] Rentizelas AA. Tolis AJ, Tatsiopoulos IP. Logistics issues of biomass: The storage problem and multi-biomass supply chain. Renewable Sustainable Energy Rev 2009; 13: 887-97. http://dx.doi.org/10.1016/j.rser.2008.01.003

[19] Chiueh P-T, et al. Implications of biomass pretreatment to cost and carbon emissions: Case study of rice straw and Pennisetum in Taiwan. Bioresource Technology 2012; 108: 285-94. http://dx.doi.org/10.1016/j.biortech.2012.01.006

[20] Caputo AC, et al. Economics of biomass energy utilization in combustion and gasification plants: effects of logistic variables. Biomass Bioenergy 2005; 28(1): 35-51. http://dx.doi.org/10.1016/j.biombioe.2004.04.009

[21] Searcy $\mathrm{E}$, et al. The relative cost of biomass energy transport. Appl Biochem Biotechnol 2007; 136-140: 639-52.

[22] Perpina $\mathrm{C}$, et al. Methodology based on Geographic Information Systems for biomass logistics and transport optimisation. Renewable Energy 2009; 34(3): 555-65. http://dx.doi.org/10.1016/j.renene.2008.05.047

[23] Ebadian $\mathrm{M}$, et al. A new simulation model for multiagricultural biomass logistics system in bioenergy production. Biosyst Eng 2011; 110(3): 280-90.

http://dx.doi.org/10.1016/j.biosystemseng.2011.08.008

[24] Tatsiopoulos IP, Tolis AJ. Economic aspects of the cotton stalk biomass logistics and comparison of supply chain methods. Biomass Bioenergy 2003; 24: 199-14. http://dx.doi.org/10.1016/S0961-9534(02)00115-0

[25] Ravula PP, Grisso RD, Cundiff JS. Comparison between two policy strategies for scheduling trucks in a biomass logistic system. Bioresource Technol 2008; 99(13): 5710-21. http://dx.doi.org/10.1016/j.biortech.2007.10.044

[26] Sokhansanj S, et al. Techno-economic analysis of using corn stover to supply heat and power to a corn ethanol plant Part 1: Cost of feedstock supply logistics. Biomass Bioenergy 2010; 34(1): 75-81. http://dx.doi.org/10.1016/j.biombioe.2009.10.001

[27] Delivand MK, Barz M, Gheewala SH. Logistics cost analysis of rice straw for biomass power generation in Thailand. Energy 2011; 36: 1435-41.

http://dx.doi.org/10.1016/j.energy.2011.01.026
[28] Interest Rate list by country. 2012 [cited 20123 July]; Available from: http://www.tradingeconomics.com/interestrates-list-by-country

[29] Shinners KJ, et al. Comparison of wet and dry corn stover harvest and storage. Biomass Bioenergy 2007; 31(4): 21121.

http://dx.doi.org/10.1016/j.biombioe.2006.04.007

[30] Turhallow A, Wilkerson E, Sokhansanj S. Cost methodology for biomass feedstocks: Herbaceous crops and agricultural residues. Bioenergy Resource Eng Syst US 2009.

[31] Khalid AG. Construction cost forecasting model. University Technology Malaysia: Malaysia 2008.

[32] Gadde B, Menke C, Wassmann R. Rice straw as a renewable energy source in India, Thailand, and the Philippines: Overall potential and limitations for energy contribution and greenhouse gas mitigation. Biomass Bioenergy 2009; 33(11): 1532-46.

http://dx.doi.org/10.1016/j.biombioe.2009.07.018

[33] Painter K. Costs of owing and operating farm machinery in the Pacific Northwest. University of Idaho: US 2011.

[34] Huisman W, Venturi P, Molenaar J. Costs of supply chains of Miscanthus giganteus. Industrial Crops Products 1997; 6: 353-66.

http://dx.doi.org/10.1016/S0926-6690(97)00026-5

[35] Sabri, Interview of Logistics cost analysis (B-II) area. MADA Jerlun, Northern region of Malaysia 2012.

[36] Leboreiro J, Hilaly AK. Biomass transporation model and optimum plant size for the production of ethanol. Bioresource Technol 2011; 102: 2712-23. http://dx.doi.org/10.1016/j.biortech.2010.10.144

[37] Singh J, Panesar BS, Sharma SK. Geographical distribution of agricultural residues and optimum sites of biomass based power plant in Bathida, Punjab. Biomass Bioenergy 2011; 35: 4455-60.

http://dx.doi.org/10.1016/j.biombioe.2011.09.004

[38] Cundiff JS, Marrsh LS. Harvest and storage costs for bales of switchgrass in the Southeastern United States. Bioresource Technol 1995; 56: 95-101.

http://dx.doi.org/10.1016/0960-8524(95)00166-2

[39] Malik, Interview of logistics cost analysis (F-IV) area. F-IV 2012.

[40] IRRI. Husk and straw properties. 2009 [cited 201225 June]; Available from: http://www.knowledgebank.irri.org/rkb/index. php/rice-milling/contributions-and-references-milling/furtherinformation-byproducts/husk-and-straw-properties

[41] Hamelinck CN, Suurs RAA, Faaij AC. International bioenergy transport costs and energy balance. Biomass Bioenergy, 2005; 29(2): 114-34.

http://dx.doi.org/10.1016/j.biombioe.2005.04.002

[42] Carlos RM, Khang DB. Characterization of biomass energy projects in Southeast Asia. Biomass Bioenergy 2008; 32(6): 525-32.

http://dx.doi.org/10.1016/j.biombioe.2007.11.005 